Revistade
Economila
Contemporâned

\title{
A POLICY MIX TO PREVENT A NON-COMMONS TRAGEDY FOR COLLECTIVE FOREST RESERVES IN AGRARIAN SETTLEMENTS IN NORTHWEST MATO GROSSO
}

\author{
R.B. Davenport ${ }^{a}$ \\ P.H. May ${ }^{b}$ \\ P. Nogueirac \\ P.C. Nunes ${ }^{d}$ \\ ${ }^{\text {aPhD }}$ candidate at the University of California, Santa Cruz, USA.

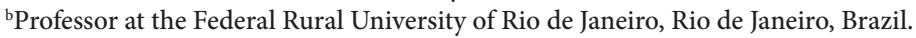 \\ 'Master of Sustainable Development Practice, Federal Rural University, Rio de Janeiro, Brazil. \\ dJuruena Rural Development Association (ADERJUR), Mato Grosso, Brazil.
}

Manuscript received on 2015/10/23 and accepted for publication on 2016/11/21.

\begin{abstract}
Agrarian reform settlements have recently been identified as a major contributor to ongoing deforestation in the Brazilian Amazon. Collective forest reserves were established in some settlements to thwart forest loss, but settlers usually do not recognize forest commons, opting instead for continued private accumulation through forest clearing, or a "non-commons" tragedy. Pathways toward ensuring the viability of common-pool management in settlements remain unclear. Our case study focused on two similarly sized settlements in neighboring municipalities in Northwest Mato Grosso, Brazil, each with formally designated collective forest areas. In one, deforestation shifted into the collective reserve and intensified; in the other, deforestation stabilized and the collective reserve was protected. In the latter, settlers understood their collective forest reserve as a commonly held asset, with two commercially viable settlement cooperatives involved in Brazil nut (Bertholletia excelsa) extractivism and added value processing. We analyze differences between the
\end{abstract}

Corresponding author: R. B. Davenport

Email address: rbdavenp@ucsc.edu 
two settlements using Elinor Ostrom's framework for analysis of socio-ecological systems, and identify the locally applied policy mix ensuring the viability of a forest commons. The study concludes that "top-down" efforts to institutionalize collective governance over remaining forests will likely fail in most settlements, without a focus on alternative livelihood opportunities synergetic with forest tenure.

KEYWORDS: Brazilian Amazon; agrarian reform settlements; collective reserves; common property resource management; institutions.

JEL CODES: Q15; Q57; P48. 


\section{UM MIX DE POLÍTICAS PARA EVITAR A PRIVATIZAÇÃO DOS RECURSOS NATURAIS NAS RESERVAS FLORESTAIS COLETIVAS DOS ASSENTAMENTOS RURAIS NO NOROESTE DE MATO GROSSO}

RESUMO: Os assentamentos da reforma agrária foram recentemente identificados como um dos principais contribuintes ao contínuo desmatamento na Amazônia brasileira. Reservas florestais coletivas foram estabelecidas em alguns assentamentos para impedir a supressão de florestas, mas os assentados geralmente não reconhecem os bosques coletivos, optando pelo contínuo acúmulo privado de bens e capital através do desmatamento: uma tragédia dos recursos naturais "não-comuns" ou não-coletivos. Caminhos para garantir a viabilidade da gestão de recursos coletivosnos assentamentos permanecem obscuros. Nosso estudo de caso focalizou dois assentamentos de tamanho semelhante, em municípios vizinhos no Noroeste do Mato Grosso, Brasil, ambos contando com áreas de floresta coletiva formalmente designadas. Em um dos assentamentos, o desmatamento se deslocou para a reserva coletiva e se intensificou. No outro, em contraposição, o desmatamento se estabilizou e a reserva coletiva foi protegida. Neste último, os assentados percebiam sua reserva florestal coletiva como um ativo comunitário, com duas cooperativas formadas por assentados comercialmente viáveis, envolvidas no extrativismo de castanha-do-Brasil (Bertholletia excelsa) e no processamento da mesma para alcançar maior valor agregado. Analisamos as diferenças entre os dois assentamentos, aplicando a estrutura de critérios de Elinor Ostrom para comparar os sistemas sócio-ecológicos e identificamos o mix de políticas públicas aplicadas localmente, que viabilizaram os benefícios gerados pela floresta. $\mathrm{O}$ estudo conclui que os esforços para institucionalizar a governança coletiva sobre as florestas remanescentes iniciados "de cima para baixo" provavelmente irão fracassar na maioria dos assentamentos, se não houver um foco em oportunidades alternativas de subsistência complementares aos direitos de propriedade sobre as florestas.

PALAVRAS-CHAVE: Amazônia brasileira; assentamentos da reforma agrária; reservas coletivas; gestão coletiva de recursos naturais; instituições. 


\section{INTRODUCTION}

Government sponsored colonization of the Brazilian Amazon started in the early 1970s, leading to the creation of federal agrarian reform settlements (settlements) administered by the Institute for Colonization and Agrarian Reform (INCRA). Today federally administered settlements occupy just over $5 \%$ of the Amazon biome in Brazil, or about $265,000 \mathrm{~km}^{2}$, an area like that of the entire state of São Paulo (SCHNEIDER and PERES, 2015). While the contribution of settlements to deforestation overall has been significantly less than that caused by large landholdings (PACHECO, 2009; GODAR et al., 2014), since 2005 deforestation in INCRA settlements has not declined as steadily compared to deforestation caused by other actors and under other land tenure arrangements (INPE, 2015; BRANDÃO et al., 2013). Settlements now represent one of the principal sources of continuing deforestation in the region (SCHNEIDER and PERES, 2015). The biophysical pattern of deforestation in settlements is well documented (ALDRICH et al., 2006), patterns driven in part by governance conditions and state policy (ALSTON et al., 1999; FEARNSIDE, 2005; ALMEYDA ZAMBRANO et al., 2010).

This does not imply, however, that state policies for land tenure in the Brazilian Amazon match with practices on the ground. For example, to counter forest loss in past attempts to comply with the Brazilian Forest Code $^{1}$, INCRA demarcated several collective forest reserves in settlements and has designated some as "forest settlements". Under the Forest Code, properties are required to maintain $80 \%$ of land in the Amazon biome under natural vegetation, known as a "Legal Reserve" (LR). In theory, in INCRA settlements collective LRs are designed to establish a common forest area equivalent to the amount of land that would formerly have been designated on individual lots. Individual lots still are required to preserve áreas de proteção permanente, or permanent protected areas along streams and on steep slopes, but are partially exempted from LR requirements once a collective reserve is demarcated.

Colonist settlers in the Brazilian Amazon however rarely have experience with collective land management and may view unoccupied forests in settlements as lands open to individual appropriation. The governance issue remains: how to maintain collective forest reserves? Regarding collective or common pool natural resource management, Elinor Ostrom identified how shared rules, norms, and strategies govern

\footnotetext{
As revised by Federal Law 12,727, 17 October 2012. Available at:<www.planalto.gov.br/ccivil_03/_
} Ato2011-2014/2012/Lei/L12727.htm>. 
the commons (OSTROM, 1990, 2005, 2010). In numerous case studies on functioning common-pool resource management, Ostrom and her followers often modeled the viability of collective action in part on the existence of social norms or trust amongst resource users, or social capital. These were often local or autochthonous rules systems operating with some autonomy from the State (AGRAWAL, 2007). But research has also shown how local rules emerge in tandem with state policy. For example, Cronkleton and Larson (2015) showed that settlers in the Peruvian and Ecuadorian Amazon were empowered to regulate the allocation and use of land within a settlement and build mechanisms to mediate conflicts. These institutions however did not arise from the formal definition of property rights alone, but rather from social networks that supported the restoration or maintenance of traditional collective use rights and management rules.

Settlement communities in the Brazilian Amazon however tend to lack experience with traditional systems of land management, and our question is if and how social trust and commons institutions can emerge from scratch. The comparative case study analysis that follows seeks to illustrate the development, or lack thereof, of institutions supporting collective LR in two proximate settlements in northwest Mato Grosso, a region subject to significant deforestation pressure. Our paper is structured as follows. In the second section, we provide background information on development and occupation in Northwest Mato Grosso (NW MT), describing the two case study settlements and their history of occupation and land use change. In the third section, we outline the land use change, socioeconomic and institutional characteristics that differentiate the two sites, despite their physical proximity and similar logistical conditions. In doing so, we employ Ostrom's framework for analysis of socio-ecological systems (SES) (OSTROM, 2007, 2009), in which social capital is one of over 40 variables. In the fourth section, we discuss the observed experience with collective LR areas, and consider our findings in light of the SES analytical framework. In the final section, we advance the case for more widespread implementation of collective reserves in settlements as part of a unified policy mix contributing to forest governance in the Brazilian Amazon.

\section{THE STUDY AREA AND POLICY CONTEXT}

NW MT is a humid tropical forest (Submontane Open and Dense Ombrophilous Forest, IBGE, 2004) region about the size of Guatemala $\left(107,622 \mathrm{~km}^{2}\right)$. The region consists of seven municipalities: Aripuanã, Castanheira, Colniza, Cotriguaçu, Juína, Juruena, and Rondolândia. Its population of about 120,000 is now $62 \%$ urban. 
NW MT was colonized in the 1970s by private land corporations which received public concessions in return for infrastructure development and technical support, enabling them to speculate on land sales to farmers from southern Brazil who hoped to exchange small parcels in the South for significantly larger holdings in the Amazon. Most colonists turned to extensive cattle ranching and unauthorized logging, while others became gold and diamond miners. These enterprises became NW MT's primary land use activities (TITO et al., 2011).

By 2012, although deforestation had proceeded apace, over $80 \%$ of NW MT's original 104 thousand $\mathrm{km}^{2}$ of primary forest cover remained. Forest remnants were located within 11 indigenous areas (37\% of remaining forest cover) and in nine Conservation Units (5.5\% of remaining forest cover) (Figure 1). The remaining 57.5\% of forest cover was located on private properties ranging from large ranches to small farms, and in agrarian reform settlements (MAY et al., 2012)

\section{Figure 1 - Location of settlements in NW MT, identifying two case study areas}

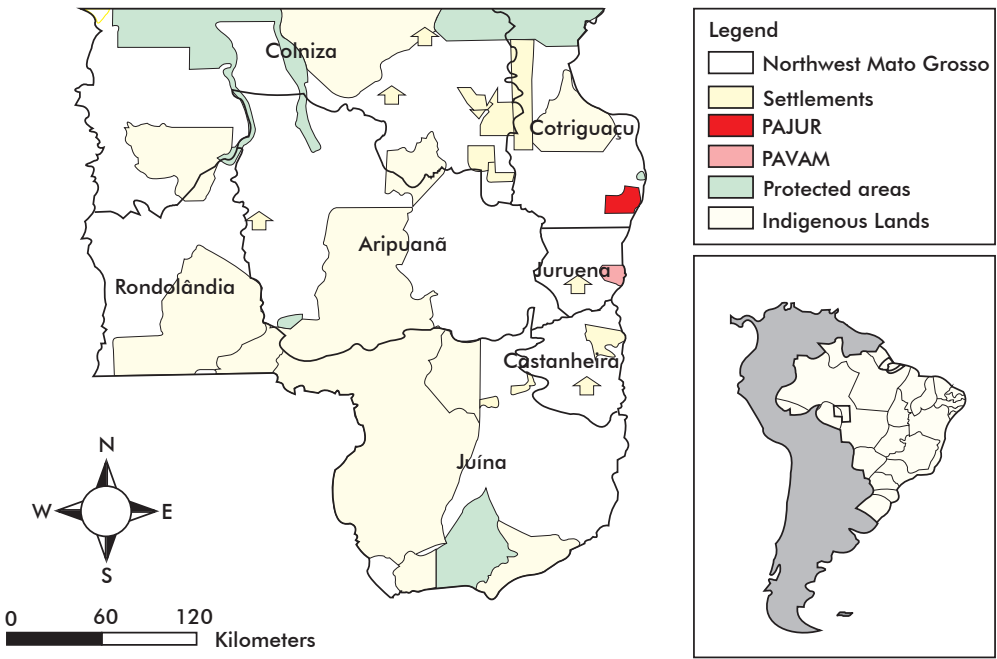

Source: Authors' elaboration based on geographic data on demarcation of indigenous lands (FUNAI), protected areas under the SNUC (MMA) and agrarian reform settlements (INCRA).

Beef cattle ranching is the predominant agricultural enterprise in NW MT. Mato Grosso hosts the largest livestock population in Brazil (28.4 million head of cattle); only one municipality in NW MT - site of a major slaughterhouse financed by the Brazilian National Development Bank - has over 642,500 head (IBGE, 2014). Cattle in Brazil are generally managed at low stocking rates (average $1.08 \mathrm{AU} /$ ha in the Amazon) with little attempt at pasture renewal or intensification, implying that 
growth in the herd will mean increasing deforestation. The Development Bank has deliberately encouraged this expansion by financing slaughterhouse expansion without heed for the proximity of remaining intact forests, while rural credit to family farmers fosters herd expansion and fencing with similar results (SMERALDI and MAY, 2009).

Recognizing the threat to remaining forests in NW MT, international donors in collaboration with state and federal agencies pledged support to a series of projects including the "Pilot Program for the Protection of Brazilian Rainforests" G-7 Pilot Program and a regional Global Environment Facility (GEF) sponsored project implemented jointly by the United Nations Development Program (UNDP) and the state government (hereafter UNDP/GEF), both of which sought to enhance land use management capacity by local governments and producer associations in NW MT. The G-7 Pilot Program and UNDP/GEF projects both constituted multi-faceted attempts to build conditions for sustainable development in NW MT. They were comprised of support for decentralization of environmental administration; consolidation and increase in the area and number of protected areas; consultation with regional stakeholders in support of mandated social, economic and ecological zoning plans; and agroenvironmental measures. The latter were focused in large measure on settlements in the buffer zones of protected areas and indigenous lands.

Agroenvironmental measures included in programs addressed to settlements in NW MT included: technical assistance for soil and water conservation; restoration of degraded land; silviculture and agroforestry systems; technical assistance; non-timber forest products; and low impact forest management. Programs for subsidized credit, product certification and incentives for added-value processing of forest products were also included. These projects sought to intervene in the institutional context by putting into practice a set of instruments and aligned state policies, supporting local efforts at social organization, and providing technical assistance on various fronts.

In a related study (DAVENPORT et al., 2017), we assessed how such pilot project agroenvironmental measures matched with deforestation dynamics over time across three settlements in NW MT. In the current article, we focus specifically on how these pilot project measures contributed to the relative sustainability of collective LR areas. We sought to understand how cooperative, rules-based systems for collective or common-pool forest management may emerge, despite contradictory broader political economic trends. Key to explaining land use decisions and resultant forest conditions we are concerned with "how a particular governance arrangement fits the local ecology, how specific rules are developed and adapted over time, and whether users consider the system to be legitimate and equitable" (OSTROM, 2010). 


\section{OBJECTIVES AND METHODS}

To appraise the influence of policy instruments and technical interventions in the institutionalization of collective forest management, our initial sources were primary and secondary data associated with monitoring and impact assessment during the G-7 Pilot Program and UNDP/GEF projects (GONÇALVES, 2009; TITO et al., 2011). These historical data were complemented with further analysis on the correlation of land use policies with deforestation rates within 12 settlements throughout NW MT (NOGUEIRA, 2014). Forest cover data analysis included baseline and year-by-year changes in forest stocks within each settlement from 1997 to 2012, mapped using annual deforestation data, compared with regional deforestation rates (NOGUEIRA, $2014)^{2}$. We calculated the total area of forest remnants at the outset of the settlement, and then evaluated the year by year progression of deforestation in terms of the percentage of original forest cover remaining.

In addition to historical land use data, we carried out semi-structured interviews with key informants representing practitioners and stakeholders in the field. We aimed to: i) comprehend the process of creation and implementation of the collective LR at Vale do Amanhecer Settlement Project (PAVAM) and Juruena Settlement Project (PAJUR); and ii) identify socio-economic and institutional factors that positively or negatively affected the implementation and maintenance of the collective LR areas within these settlements, informed by the SES analytical framework (OSTROM, 2007, 2009).

\section{RESULTS}

We here describe deforestation dynamics for the selected agrarian reform settlements (see Figure 2), both under the administration of Brazil's Federal Institute for Colonization and Agrarian Reform (INCRA):

1. PAJUR - municipality of Cotriguaçu: 30,792 ha, 467 households, inaugurated in 1997, settled formally in 2002, but with occupants moving into the settlement prior to inauguration.

2. PAVAM - municipality of Juruena: 14,400 ha, 243 households, inaugurated in 1998, settled in 1998.

\footnotetext{
2 Derived from imagery analyzed annually for Prodes (Legal Amazon Deforestation Monitoring System) based on Landsat imagery and developed by the Brazilian Institute of Space Research - INPE, complemented by a state level Deforestation Monitoring System based on Landsat imagery developed by the State Environmental Agency - SEMA/MT.
} 
Figure 2 - Accumulated deforestation (1997-2014) and remaining forest cover (2014) at PAJUR and PAVAM

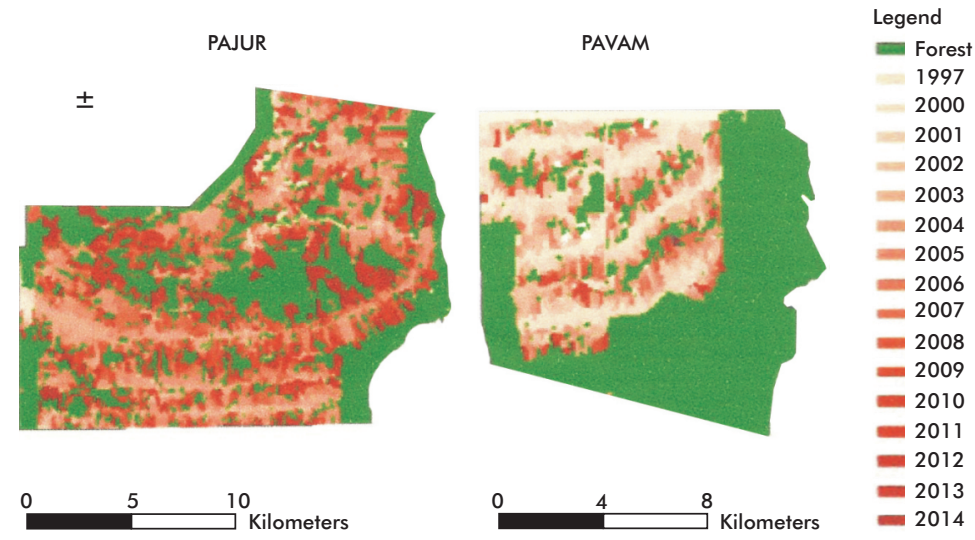

Note: in PAJUR, the collective LR is separated amongst three non-contiguous areas, one located in the central area and two on the western and eastern fringes of the settlement, while in PAVAM the LR is a contiguous forest area encompassing the settlement along the southern and eastern border.

Source: Authors' elaboration based on data from Prodes/INPE.

Table 1 indicates percentage of original forest cover in the two settlements starting from the year of their initiation. In 2014, PAVAM had 54\% of original forest area remaining, 16 years after settlers began to occupy their lots in 1998. In contrast, PAJUR had only $37 \%$ of original forested area in 2014, although its effective occupation had begun four years later than PAVAM. In the accompanying graph (Figure 2), both PAVAM and PAJUR exhibit deforestation rates greater than that of the NW region as a whole, but the trend in PAVAM is a decline in annual deforestation toward the regional mean, PAJUR continues to deforest relatively rapidly, at a velocity greater than that of the region as a whole (see Figure 3).

\section{Table 1 - Accumulated deforestation (1997-2014) and remaining forest cover (2014) at PAVAM and PAJUR}

\begin{tabular}{lccccc}
\hline Settlement & Area (ha) & $\begin{array}{c}\text { Forest Remnants } \\
\text { in 1997 (ha) }\end{array}$ & $\begin{array}{c}\text { Deforestation } \\
\mathbf{1 9 9 7 - 2 0 1 4} \text { (ha) }\end{array}$ & $\begin{array}{c}\text { Remaining Forest } \\
\text { Cover 2014 (ha) }\end{array}$ & $\begin{array}{c}\text { Remaining Forest } \\
\text { Cover 2014 (\%) }\end{array}$ \\
\hline PAVAM & 14,400 & 13,108 & 6,672 & 7,727 & 54 \\
PAJUR & 30,792 & 27,466 & 19,293 & 11,499 & 37 \\
\hline
\end{tabular}

Source: Prodes/Inpe. Own Analysis. 
Figure 3 - Rate of deforestation (\% of original forest cover degraded per year) in NW MT, PAVAM and PAJUR: 2001-2012

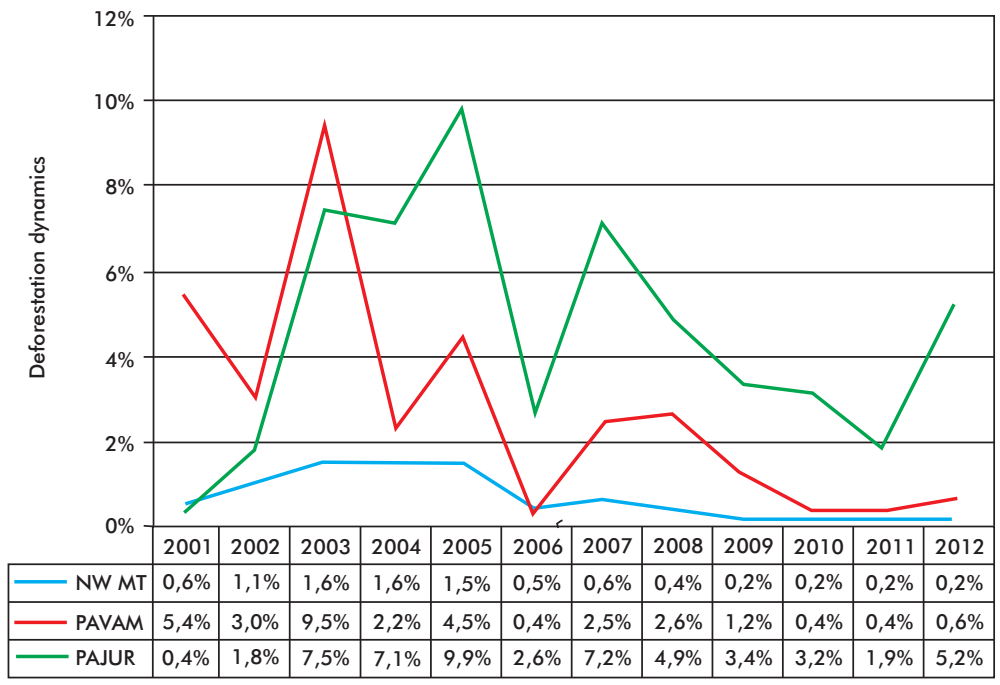

Source: Authors' elaboration based on data from Prodes/INPE.

Our socio-economic analysis relied on data provided in Davenport et al. (2017) with respect to PAVAM and regional agro pastoral production trends, and research reported by Eiró and Tricaud (2010) focused on conditions in PAJUR. The former was concerned with characterizing production systems, labor requirements and net returns associated with adoption of agroforestry and forest product extractivism, while the latter was concerned with income and land use and the difficulty of administering forest legal reserves, both for individual lots and in collective areas.

Davenport et al. (2017) analyzed economic performance by identifying the prevalent operations for cattle and mixed cattle (beef and dairy) systems, comparing these production systems with alternatives including agroforestry and non-timber forest product extraction and processing, the latter focused on Brazil nuts (Bertholletia excelsa). The regional revenue standard for well managed dairy \& beef enterprises by smallholders, with an average 39 ha of pasture, yielded gross US\$212/ha.yr ${ }^{-1}$, with $45 \%$ costs yielding annual net revenues of US $\$ 4,547 / \mathrm{yr}^{-1}$.

We also considered the historical development of socio-economic conditions within the two settlements in our case study. In PAVAM in 2005, for $70 \%$ of its households over half of their incomes came from working outside of the settlement, often in timber extraction or processing, or in urban areas. Only $12 \%$ had farm-based 
incomes equal to the Brazilian minimum wage (US\$ 150 in $2005^{3}$ ). The majority was below the poverty line (VARGAS, 2006). Settlers in PAJUR, similarly, in 2009 derived an average of $66 \%$ of their incomes from off-farm activities in the timber industry or in urban areas. Notwithstanding the lack of a viable income from livestock, 69\% of settlers in PAJUR also opted to use the land for pasturing cattle as a form of financial insurance (EIRÓ and TRICAUD, 2010).

By 2012, however, socio-economic conditions had changed, at least in PAVAM. In 2013, two cooperatives: Associação de Mulheres Cantinho da Amazônia (AMCA), formed by a group of 120 women, and Cooperativa dos Agricultores do Vale do Amanhecer (COOPAVAM), were operating within PAVAM, with support from a sequence of pilot projects underway in NW MT as previously described. These cooperatives were processing Brazil nuts procured from the settlement's collective LR. The monetary value derived from this activity for Brazil nut flour and oil was US\$ 71 ha $^{-1} \mathrm{yr}^{-1}$ with $10 \%$ costs, yielding an estimated US\$ 461,880 in annual net revenue, if based only on the Brazil nuts procured solely from PAVAM's 7,200-hectare collective LR. With approximately 70 direct participants in the cooperatives, and assuming 10\% costs, this would yield US\$ 6,573 user $^{-1} \mathrm{yr}^{-1}$ net revenue: a $45 \%$ gain in annual net revenue over the regional standard for well-managed mixed beef and dairy cattle operations. As such, livelihoods among PAVAM settlers shifted from one based primarily on cattle to one which derived a significant share of income from Brazil nut trees as commonly held assets within the settlement itself. In addition, cooperatives within PAVAM also had begun in 2012 to source additional raw Brazil nuts from surrounding areas: from four indigenous territories, one Extractive Reserve and miscellaneous smallholders, yielding significant additional revenues. In this value chain, indigenous communities, reserve inhabitants and small holders delivered raw nuts to the settlement under favorable price contracts: in 2013 the cooperative's price for raw Brazil nuts had risen to BRL 3.00 $\mathrm{kg}^{-1}$, compared to BRL $0.60 \mathrm{~kg}^{-1}$ in 2002.

An institutional analysis carried out in PAVAM in 2012 and 2013 applied questionnaires and semi-structured interviews with individual farmers, designed to record the experience of farmers' interaction with various government agencies and project entities. Cross-referencing the latter, researchers also conducted a group workshop with PAVAM farmers, to appraise the historical development of land use decision-making processes and institutional arrangements. Settlers worked to identify community events, deforestation trajectories and factors involved in land use decisions in each year from 1998 - year of the founding of the settlement - up to 2012. In PAJUR,

\footnotetext{
$3<$ http://www.debit.com.br/consulta30.php?indice=salario_minimo $>$.
} 
field research undertaken in 2009 by collaborating researchers had engaged settlers in discussion of their common experience through rapid rural appraisal (EIRÓ and TRICAUD, 2010).

Based on combined remote sensing, socio-economic and institutional analysis, the SES characteristics of PAJUR's collective forest areas were compared with PAVAM's collective forest area, applying variables from the SES analytical framework developed by Ostrom $(2007,2009)$. We identified a set of 21 "second tier" SES variables that best encapsulated institutional differences between the two settlements' collective forest reserves. Appendix 1 details our comparative analysis of the differences found between PAVAM and PAJUR along these 21 SES variables, that are further described and justified below.

Many SES variables encapsulated clear discrepancies between PAVAM's and PAJUR's respective SES indicators. The most striking difference is that in PAJUR the collective LR areas do not function as a common pool resource at all, but as terra nullius (non-property) or indeed as a "non-commons" (MAY, 1985) subject to appropriation and conversion to res privae (private property), in accordance with Roman legal terms still used in property theory. Deforestation to secure private land tenure in a context laden with risks is the classic dynamic of the Brazilian Amazon (ARAUJO, 2009) and construction of roads prior to the installation of PAJUR's basic infrastructure stimulated unauthorized settlement. As such, the history of use of the resource (U3 in the Appendix) was also key to the evolution of the SES. According to one of our respondents, four families were already living within the collective areas when these areas were demarcated under INCRA jurisdiction as part of the settlement plan. Nothing was done to remove these initial settlers, and these and subsequent occupations inside the collective areas were undertaken by surrounding loggers, ranchers and smallholders who knew that INCRA would eventually distribute the land to designated settlers, but who also knew that land use restrictions were not enforced by INCRA or other state agencies.

By 2012, approximately 200 families occupied 4,000 hectares in PAJUR's collective LR areas. In terms of ecological outcomes (in line with the rate of deforestation described for each settlement in Figure 3) we observed that deforestation took a significant uptick in 2012, from $2 \%$ to $5 \%$, whereas continued land tenure insecurity has fostered continued deforestation by occupants with the expectation that formal private property rights will eventually be conceded. Some of the occupants live within the occupied areas, while others do not and only maintain farms, mostly involving beef and dairy cattle ranching, as well as some cocoa and coffee plantations. Those settlers that only farm in the collective LR areas tend to reside in formally demarcated lots outside the collective LR areas, or in nearby towns. Interview respondents offered 
several factors associated with occupation of the collective LR areas and the failure to establish common pool arrangements: i) a lack of discussion with settlers to explain the collective LR areas and to raise awareness about social responsibility for their protection and sustainable use; ii) little cultural appreciation for commonly held assets and iii) lack of enforcement by INCRA, even after certain settlers' complaints about the invasion of the collective LR areas.

PAJUR saw minimal investments into the institutional and economic development of collective forest areas. Settlers in PAJUR had received support to gather Brazil nuts on a neighboring property managed by the international branch of the French Forest Service (ONF). These interventions encouraging Brazil nut harvesting outside of the settlement were taken up by a group of approximately 30 settler families from PAJUR. However, settlers declined ONF's proposal that they form cooperatives inside PAJUR. This refusal came in part, because ONF was not in the position to negotiate the conditions necessary to achieve social trust in collective property with government agencies, to enforce land use rules, or assume the costs of obtaining authorization for sustainable production within the collective LR areas.

Our interview respondents offered that settlers in PAJUR failed to realize common-pool resource management because they had not been made conscious of social responsibility to protect collective forests. On the contrary, however, based on our observations the local population understood collective management as incoherent with the reality of accumulation strategies in an informal property-rights system. Thus, the formal mandate to conserve collective LR areas inside PAJUR has had little relevance in the context of property-rights rules based on the de facto private appropriation of land. The operational rules in PAJUR's collective LR areas have included black market land sales and land re-concentration, volatile prices, producers assuming most economic risk, and undocumented production. Aiming to represent their own interests, settlers active inside the collective LR areas established an association that was especially active after the collective LR was formally demarcated in 2003. The collective LR areas initially enjoyed little support from local public agencies in attending to basic needs, including upkeep of a precarious road infrastructure. Currently, however, the municipal government actively communicates with and supports the occupants of the collective LR areas by working to address road maintenance and the issuance of taxation invoices for farm products, even with the illegitimate character of individual land occupation in these areas.

Concerning public policy, INCRA has started to register its territories, including PAJUR, within the nationally mandated environmental regulatory system known as the Cadastro Ambiental Rural (CAR) or rural land use registry. As of 2015, INCRA plans to apply the CAR for entire settlements in Mato Grosso, collectively, rather than for individual 
demarcated lots. While the CAR registers the location of land and water features, however, it is distinct from the administration of land tenure rights. As the collective CAR will document the environmental geographical conditions of the settlement as a whole, it will not document individual land tenure. As such, a settlement-wide CAR in PAJUR will likely not be able to attribute responsibility for deforestation to specific occupants within the collective LR areas. Our respondents reported that INCRA's current view regarding the collective LR areas in PAJUR is that they should no longer be administered as collective LR areas at all, whereas the environmental deficit incurred by the conversion of these areas into individual lots should be compensated by offsetting deforestation with other forested areas elsewhere in the biome.

The other settlements analyzed in this paper, PAVAM, demonstrated development of an alternative SES organized around common property arrangements. In this case, INCRA was deeply involved in the design and planning of the settlement, with support from a decade-long series of pilot projects. INCRA sought there to create a settlement that could serve as a model in terms of forest management and conservation in the Amazon region. Lots were demarcated before legal beneficiaries arrived, and roads were built parallel to small streams, to avoid degradation of permanent protected areas in accordance with environmental regulations. Settlers' perspectives in PAVAM were synergetic with formal government rules, reflected in social esteem for this settlement's collective LR of 7,200 hectares, mapped and authorized for extractive forest production through a collectively held state environmental license or Licença Ambiental Única (LAU), signed by the State Environmental Secretariat (SEMA-MT) in May of 2012.

The LAU held by PAVAM is a comprehensive environmental license encompassing long-term environmental planning for the settlement as a whole, while it legally certifies settlement cooperatives to engage in sustainable production of Brazil nut oil, food products and other processing and marketing activities. The LAU is designed as a land use implementation instrument that - although it was operational in Mato Grosso since the late 1990s primarily with large properties - most logically would act as a successor to the CAR in that it goes beyond registering land use to actually legalizing and certifying sustainable forest management. To our knowledge no other settlements has attained a settlement-wide LAU in Mato Grosso. Throughout the state, few private land managers have been able to obtain the LAU for sustainable forest management, due to transaction costs and administrative bottlenecks. For PAVAM, securing the LAU entailed a six-year process, involving significant investments and commitments by institutional actors (UNDP/GEF, SEMA-MT and INCRA). Under the LAU, the forest area is managed as a single continuous area with a geo-referenced population of 800 Brazil nut trees. Certification for non-timber forest production was tied to the mapping and ecological maintenance of the collective reserve, along with 
monitoring against invasions through community-based arrangements. Interestingly, the license is effective regardless of formal land tenure conditions on individual demarcated lots in the settlement. The collective rights and responsibilities regarding the forest reserve are fully documented by the state and are viewed as legitimate by the settlers themselves.

Our results indicated that the outcomes of this system included the reduction of deforestation rates to a minimum by 2012 (see Figure 3) and the sustainability of the common property arrangements. Such stark differences can also be attributed to the operational rules involved in production and market contracts. In contrast to PAJUR, economic value accruing to the collective LR was due to human-constructed facilities for added value processing and the development of market contracts. The operational rules reflected the distribution of economic risk between producer, intermediary and consumer. To finance the procurement of raw Brazil nuts by the two settlement cooperatives, the National School Meals Program and the Anticipated Acquisition Program - both managed by the Federal Supply Company (CONAB) within the Ministry of Agriculture - provided US\$580,000 in advance credit for 2013. These contracts with CONAB have allowed the cooperatives to process Brazil nut derived foods, including pasta and cookies, to reach 40,000 persons in seven local municipalities in NW MT, as well as selling oil and other products for cosmetics manufacturers and consumers. In addition, these cooperatives were granted significant tax relief on reported production.

Further regarding local perception of the functionality of the SES, settlers in PAVAM identified the practical influence of specific pilot project interventions. Settlers valued highest courses and training, provision of credit, technical assistance, social organization, the elaboration of a settlement-level environmental license, the installation and outfitting of the Brazil nut factory, and market channels. These interventions supported and complemented the maintenance and protection of the collective reserve. Although cooperative processing and marketing of Brazil nut products in PAVAM involves only approximately 70 households, just under a third of the total in the settlement, we observed a broader social legitimacy for common pool arrangements, reflected in a dramatic shift in local production practices by settlers there, to the extent that by 2012 no farmers were observed setting fires to manage pasture or to clear additional forest.

In contrast, inside PAJUR's collective LR our respondents reported that settlers have had a greater incentive to deforest to secure land tenure, than those located on demarcated lots. The principal areas subject to recent burning and deforestation are in fact located within the collective LR areas. Property-rights within the collective LR areas are unauthorized, with informal boundaries between private users, enforced by local fiat, whereas operational rules include black market land sales and land 
accumulation, volatile prices, producer risk, and undocumented product sales. Furthermore, according to our respondents, no legal procedures exist to evict undocumented occupants of the collective LR areas. Paradoxically, the formal rules that designated collective areas for forest conservation have served to produce an opposite situation from what was intended.

\section{DISCUSSION}

In this section, we discuss the observed experience with collective LR areas, and consider our findings in light of the SES analytical framework. Key to our discussion is our focus on the social structure and function of the formally designated collective forest areas in the two settlements. This is distinct from focusing on land use under formal individual tenure, which is subject to different rules. Remarkably, individual land tenure security on demarcated lots is actually slightly higher in PAJUR compared to PAVAM: respectively $88 \%$ vs. $68 \%$ of the occupants are INCRA recognized beneficiaries. However, officially demarcated individual tenure, we suggest, has not been a determining variable in the rather stark difference between SES governing the respective collective forest reserve areas.

We suggest that the sustainability of a common property system in PAVAM, and failure in PAJUR, has been the degree of alignment, over time, between collective action and formal governance design. We observed that the pilot projects operative in PAVAM were able, over at least six years (roughly 2006-2012), to foment collective action alternative to the typical pattern of illegal timber extraction, squatting and extensive cattle ranching. This took the form of aligning state policy instruments with local interventions. These interventions and policy instruments were applied in the following overlapping sequence: 1 ) setting priorities by mapping the potential of the remaining forest; 2) technical assistance and training in community forest management; 3) cooperative social organization; 4) formalizing the LAU environmental license and certification for sustainable production; 5) material investments in buildings and equipment; 6) market development, credit financing and the elaboration of contracts with surrounding indigenous communities; 7) contracts with private companies and with $\mathrm{CONAB}$; 8) national and international recognition of effectiveness through public communications; 9) support to expand Brazil nut production (DAVENPORT et al., 2017). The temporal sequencing of interventions and instruments in PAVAM seem to have overcome political insecurity and public agency dysfunction, including limited public resources at SEMA-MT for the processing of environmental licenses for sustainable production. 
In PAVAM the collective reserve took on social legitimacy over time, and thereby became a recognized mode for collective action, through the application of state policies. This shift is even more remarkable given the fact that most settlers, coming from southern states of Brazil, had no cultural experience with collective property and little incentive to develop cooperatives. In contrast, in PAJUR a failure to establish common-pool management we suggest is not due to the lack of social capital, but due to the absence of synergies between government rules and the reality of a local socio-ecological system. In much of the Brazilian Amazon, there is little legitimacy amongst colonist settlers for the state's environmental policies, including those aspects of the Brazilian Forest Code that stipulate the maintenance of $80 \%$ of land under private management in forest legal reserves. Data from several studies in NW MT (EIRÓ and TRICAUD, 2010; DAVENPORT, 2013; RODRIGUES, 2015) attest to the "inevitability" of land use transformation to cattle ranching in this region as well as the social illegitimacy of command and control rules restricting forest conversion to pasture. The mismatch between state command and control and the outlooks of the local population, also involves NGO and pilot project intermediaries and other locally based organizations who are challenged in bridging the divide between de facto land use patterns and de jure systems for land tenure and environmental regulation.

While our case study of PAVAM shows that collective LR management can represent a means to avert continuing deforestation, systemic socio-ecological factors impede spontaneous adoption of common-pool management by settlers in the Brazilian Amazon. Besides insecure collective forest tenure, such socio-ecological conditions include the lack of bureaucratic capacity, technical assistance, cooperative infrastructure, and appropriate financing. To enable investment in collective enterprise, settlers must be able to defer returns on capital, often for several years, to permit added value industries to achieve sustainability. Although forest products may be gathered from mature Brazil nut trees already present in the landscape (more readily than from agroforestry), the structuring of processing industries and marketing strategies imply considerable delay to achieve financial viability. Our findings concur with other research suggesting that a focus on technology adoption alone is not as effective as approaches that concentrate on institutional arrangements (RICHARDS, 1997). The local absence of State actors and lack of bureaucratic coordination represent serious impediments to institutional development and effective governance in settlements ${ }^{4}$.

4 For instance, the superintendent's office for INCRA for NW MT is located in Cuiabá, over 900 km distant from the settlements under consideration, whereas in 2012 there was only a single INCRA administrator 
While ecological conditions in both settlements under consideration are favorable for the presence and distribution of Bertholletia excelsa (MORI and PRANCE, 1990) the potential for management and economic utilization of Brazil nuts and other forest products within settlements is closely tied with the development of cooperative institutions to govern these resources and to exclude competing use. For settlements, it seems clear that neither the presence of a valuable forest resource nor the formal establishment of collective tenure were sufficient by themselves to ensure the social recognition of a forest commons.

\section{CONCLUSIONS}

One of Ostrom's principal conditions for effective common-pool management is whether resource users can effectively exclude outsiders. Yet, unauthorized land occupation within and surrounding settlements is a longstanding practice (SCHNEIDER and PERES, 2015). Such occupation often begins as long as $~ 4$ years prior to the official decree of settlement status (ibidem). By the time that formal settlement is underway, significant forest areas may have already been degraded. Settlement patterns thereby subvert state rules, legitimating individual systems of resource appropriation rather than protecting the commons. Encroachment on collective forest reserves in settlements continues, we suggest, because human actors do not foresee direct benefit from these forests as common-pool resources.

However, it is impractical to posit social capital ${ }^{5}$ as a central prerequisite condition to common-pool management in settlements, when social norms in the region are aligned with the dynamic of individual property accumulation. In PAVAM, systematic accomplishments occurred in spite of prevailing cultural norms and outlooks about economic development and the state. Social capital or trust should not be viewed as a prerequisite 'stock' to common-pool approaches, but rather as emerging out of human experiences on the land and in communication with State actors and intervening

\footnotetext{
tasked with land tenure regularization for the entire NW MT region, which contains 14 settlements and over 10,000 settler families.

5 The concept of social capital has been critiqued for its lack of clarity (PORTES, 2000; PORTES and LANDOLT, 2000), and as a tautology in which social capital is assumed to be synonymous with collective action and good governance (BALLETT et al., 2007). Ishihara and Pascual (2009) took up criticism of the lack of clarity of the connections between social capital, collective action, and natural resource governance, by proposing the concept of "common knowledge" the set of understandings embedded in a given social structure, which enables putting resources to particular use.
} 
organizations. Having migrated to the Amazon from distinct regions within Brazil, some even from urban areas, very few are cognizant of the ecological characteristics of Amazonian soils or forests upon arrival. Settler communities within settlements are often fractured, responding to an individualist culture. Since they hail from distinct regions, settler colonists to the Brazilian Amazon usually lack previous experience with collective resource management (WOLFORD, 2010). Without a common experience, they have not had the opportunity to evolve social trust in support of collective action posited as necessary by Ostrom (2005).

As such, the principle finding of our case study is that effective conservation of forest cover in PAVAM has occurred through concerted attention to socio-ecological systems, over time permitting the formation of alternative livelihoods as a foundation for common-pool management. While PAVAM's collective forest reserve appeared on INCRA's maps, it only became a recognized mode for collective action, we argue, because local, NGO and state officials and technicians attended to the multiple ecological, technological and administrative aspects of managing a forest for added value goods, thereby engendering settlers' collective institutional commitment. In PAJUR, on the other hand, haphazard designation of collective LR, individual appropriation of common lands and splintered local organization unfavorable to cooperative enterprise denied the perspective for such synergies to emerge.

The viability and impact of policy instruments is a function of how well they interact with the socio-ecological systemic context (BARTON et al., 2014). But given "baseline" SES conditions in settlements in the Brazilian Amazon, theinstitutionalization of forest commons in settlements will require long-term adaptive management involving rights and responsibilities shared between local, NGO, and state actors. Given the prevailing set of practices and perceived technical options in settlements in the Brazilian Amazon - illegal logging and extensive pasture establishment through clear cutting and burning - settlers see themselves on a trajectory toward capital accumulation via forest conversion, with limited responsibility for broader social and environmental benefits. However, local institutional and technical innovations, supported by broader policy networks may have the potential to foment collective action for forest conservation. Careful settlement design and planning, emphasizing integrated approaches to ensure the social viability of forest commons, represents an unusual opportunity to address such systemic socio-ecological challenges and so combat a non-commons tragedy. 


\section{REFERENCES}

AGRAWAL, A. Forests, governance, and sustainability: common property theory and its contributions. International Journal of the Commons, v. 1, n. 1, p. 111-136, 2007.

ALDRICH, S. P. et al. Land-cover and land-use change in the Brazilian Amazon: smallholders, ranchers, and frontier stratification. Economic Geography, v. 82, n. 3, p. 265-288, 2009. doi:10.1111/j.1944-8287.2006.tb00311.x.

ALMEYDA ZAMBRANO, A. et al. Deforestation drivers in southwest Amazonia: comparing smallholder farmers in Iñapari, Peru, and Assis Brasil, Brazil. Conservation and Society, v. 8, n. 3, p. 157-170, 2010. Available at: <http://www.conservationandsociety.org/text. asp?2010/8/3/157/73805>. Accessed Dec. 23, 2016.

ARAUJO, C. et al. Property rights and deforestation in the Brazilian Amazon. Ecological Economics, v. 68, n. 8-9, p. 2461-2468, 2009.

BALLET, J.; SIRVEN, N.; REQUIERS-DESJARDINS, M. Social capital and natural resource management: a critical perspective. The Journal of Environment \& Development, v. 16, n. 4, p. 355-374, 2007.

BARTON, D. et al. Guidelines for multi-scale policy mix assessments. Technical Brief, n. 12, 2014. Available at: <http://policymix.nina.no/Portals/policymix/Documents/Research topics/ WP9/D91 Policymix Technical Brief - INTERACTIVE PDF v1 _(2).pdf >. Accessed Dec. 23, 2016.

BRANDÃO JUNIOR, A. et al. Situação do desmatamento nos assentamentos de reforma agrária no Estado do Pará. Belém, PA. Belém: IMAZON, 2013. Available at: <http://imazon.org.br/ PDFimazon/Portugues/livros/Relatorio Desmatamento nos Assentamentos no Estado do PA.pdf $>$. Accessed Dec. 23, 2016.

BRONDIZIO, E. S.; OSTROM, E.; YOUNG, O. R. Connectivity and the governance of multilevel social-ecological systems: the role of social capital. Annual Review of Environment and Resources, v. 34, n. 1, p. 253-278, 2009.

CRONKLETON, P.; LARSON, A. Formalization and collective appropriation of space on forest frontiers: comparing communal and individual property systems in the Peruvian and Ecuadoran Amazon. Society and Natural Resources, v. 28, n. 5, p. 496-512, 2015.

DAVENPORT, R. B. Feasibility and legitimacy of land use regulatory instruments in three agrarian reform settlements in northwest Mato Grosso, Brazil: the influence and role of integrated conservation and development projects. Tesis (Manejo y Conservación de Bosques Tropicales y Biodiversidad) - Centro Agronómico Tropical de Investigación y Enseñanza, Turrialba, Costa Rica, 2013.

DAVENPORT, R. B.; VIVAN, J. L. (in memoriam); MAY, P. H.; NUNES, P. C.; VARGAS, L. N.; COSTA, W. L. S.; OLIVEIRA, A. R.; RAJAO R. L. Pilot projects in northwest Mato Grosso, Brazil: outcomes and outlooks on forest governance in agrarian reform landscapes. Environmental Policy and Governance, in press, 2017.

EIRÓ, F.; TRICAUD, S. Gestão ambiental de assentamentos na Amazônia Estudo de caso do Projeto de Assentamento Juruena. In: ENCONTRO NACIONAL DA ANPPAS, 5, Florianópolis/SC, 2010. 
FEARNSIDE, P. M. Deforestation in Brazilian Amazonia: history, rates, and consequences. Conservation Biology, v. 19, n. 3, p. 680-688, 2005.

GODAR, J. et al. Actor-specific contributions to the deforestation slowdown in the Brazilian Amazon. PNAS, v. 111, n. 43, p. 15591-15596, 2014.

GONÇALVES, A. L. Sistemas agroflorestais da agricultura familiar, Noroeste de Mato Grosso: sistematização e análise. UNDP. Project BRA/00/G31. Promotion of Sustainable Use and Conservation of Biodiversity in the Frontier Forests of NW Mato Grosso, Brazil, 2009.

IBGE - INSTITUTO BRASILEIRO DE GEOGRAFIA E ESTATÍSTICA. Mapa da Vegetação do Brasil. Rio de Janeiro: IBGE, 2004. Available at: <http://www.ibge.gov.br/home/presidencia/ noticias/21052004biomashtml.shtm>. Accessed Dec. 23, 2016.

IBGE - INSTITUTO BRASILEIRO DE GEOGRAFIA E ESTATÍSTICA. Produção Pecuária Municipal. Rio de Janeiro: IBGE, 2014. Available at: <http://www.ibge.gov.br/home/ estatistica/economia/ppm/2014/>. Accessed Dec. 23, 2016.

ISHIHARA, H.; PASCUAL, U. Social capital in community level environmental governance: A critique. Ecological Economics, v. 68, n. 5, p. 1549-1562, mar. 2009.

LASTON, L. J.; LIBECAP, G. D.; MUELLER, B. Titles, conflict, and land use: the development of property rights and land reform on the Brazilian Amazon frontier. Ann Arbor: University of Michigan Press, 1999.

MAY, P. H. A modern tragedy of the "non-commons": agro-industrial change and equity in Brazil's babassu palm zone. 1985. Phd Thesis - Resource Economics, Graduate School of Cornell University, 1985.

MAY, P. H. et al. Assessment of the role of economic and regulatory instruments in the conservation policymix for the Brazilian Amazon: a coarse grain analysis. Rio de Janeiro: CPDA/UFRRJ, 2012.

MORI, S. A.; PRANCE, G. T. Taxonomy, ecology, and economic botany of the Brazil nut (Bertholletia excelsa Humb. and Bonpl.: Lecythidaceae). Advances in Economic Botany, v. 8, p. 130-150, 1990.

NOGUEIRA, P. Dinâmica de desmatamento em projetos de assentamentos na região Noroeste de Mato Grosso: uma contribuição para estratégias de baixo carbono (Dynamics of deforestation in settlement projects in the Northwest region of Mato Grosso: a contribution for low carbon strategies). 2014. Master's Thesis - Graduate Program in Sustainable Development Practice, Federal Rural University of Rio de Janeiro, Rio de Janeiro, 2014.

OSTROM, E. Beyond markets and states: Polycentric governance of complex economic systems. The American Economic Review, v. 100, n. 3, p. 641-672, 2010.

OSTROM, E. A diagnostic approach for going beyond panaceas. Proceedings of the National Academy of Sciences, v. 104, n. 39, p. 15181-15187, 2007.

OSTROM, E. A general framework for analyzing sustainability of social ecological systems. Science, v. 325, n. 5939, p. 419-422, 2009.

OSTROM, E. Governing the commons: the evolution of institutions for collective action. Cambridge: University Press, Cambridge, 1990. 
OSTROM, E. Understanding institutional diversity. Princeton: Princeton University Press, 2005.

PACHECO, Pablo. Agrarian reform in the Brazilian Amazon: its implications for land distribution and deforestation. World Development, v. 37, n. 8, p. 1337-1347, Aug. 2009.

PORTES, A. The two meanings of social capital. Sociological Forum, v. 15, n. 1, p. 1-12, 2000.

PORTES, A. LANDOLT, P. Social capital: promise and pitfalls of its role in development. Journal of Latin American Studies, v. 32, n. 2, p. 529-547, 2000.

RICHARDS, M. Missing a moving target? Colonist technology development on the Amazon frontier. London: Overseas Development Institute, 1997.

RODRIGUES, C. H. Roubaram nossa honestidade: reflexões sobre as mudanças de uso do solo no PA Nova Cotriguaçu, Mato Grosso. In: CONFERENCE ENVISIONING A SUSTAINABLE TROPICS, [s.n.], Florida, US, 2015.

SCHNEIDER, M.; PERES, C. A. Environmental costs of government-sponsored agrarian settlements in Brazilian Amazonia. Plos One, v. 10, n. 8, p. 1-23, 2015.

SMERALDI, R.; MAY, P. H. Time to pay the bill: livestock, Amazonia and conjuncture. São Paulo: Amigos da Terra Amazônia Brasileira, 2009.

TITO, M. R.; NUNES, P. C.; VIVAN, J. L. Desenvolvimento agroflorestal no noroeste de Mato Grosso: dez anos contribuindo para a conservação e uso das florestas. Brasília: PNUD, 2011.

VARGAS, L. N. Vale do Amanhecer, retrato de um assentamento: modelo de reforma agrária para a Amazônia mato-grossense? Dissertação (Mestrado) - Pós-Graduação em Agricultura Tropical, Universidade Federal de Mato Grosso, Cuiabá, 2006.

WOLFORD, W. This land is ours now: social mobilization and the meanings of land in Brazil. Durham: Duke University Press, 2010. 


\section{Appendix 1. Differences between PAVAM and PAJUR along the 21 SES variables defined by Ostrom (2005)}

\section{SES second tier variables}

(Ostrom, 2007; 2009)

PAVAM

PAJUR

\begin{tabular}{ll}
\hline Resource Systems (RS) & \\
\hline RS3 Size of resource system & $\begin{array}{l}7,200 \text { hectares of forest reserve (most of } \\
\text { which had been harvested selectively for } \\
\text { 'noble' hardwoods prior to settlement, but } \\
\text { fundamentally intact and contiguous) }\end{array}$
\end{tabular}

RS4 Human-constructed facilities

RS9 Location

\section{Resource units (RU)}

RU4 Economic value
Brazil nut processing plant consisting of several buildings and facilities involving several distinct operations (oil, flour, food processing); Roads in relatively good condition; avoiding permanent protected areas outside of the collective reserve

One continuous area along southern and eastern sides of settlement
4,000 hectares of pasture and $\sim 11,000$ hectares of remaining forest within collective reserve boundaries: (assuming 15,000 hectares total for collective LR i.e. roughly half the size of the settlement)

Roads in precarious condition, in some cases crossing permanent protected areas in lots outside of the collective reserve

Reserve separated in 3 distinct areas; complex geography
Brazil nuts processed for flour and oil: US $\$ 71 /$ ha $* 103$ hectares per user $(7,200$ ha/70 user families) $=$ estimated US $\$ 6,573$ per year per user (assuming 10\% costs); US $\$ 580,000$ in advance credit provided by the Federal Supply Company (CONAB) in 2013 in
Mixed beef and dairy: US $\$ 212 /$ ha * 20 hectares per user $=$ US $\$ 2,332$ per year per user (assuming 45\% costs)

Governance systems (GS)

GS1 Government organizations

GS2 Nongovernment organizations

GS4 Property-rights systems settlements created with strong presence by INCRA; aim to be a model in terms of forest management and conservation in the Amazon region; SEMA-MT and IBAMA (gold mining fiasco in 2004 and its repetition in 2012) also involved; difficult relationships with local government

Support from an NGO and GEF project on INCRA's design and planning of the settlements; series of overlapping integrated projects provide long term support for activities inside the settlement: Instituto Pró-Natura (1992-2005); GEF/ UNDP (2001-2010); Poço de Carbono Juruena (2010-2014); Sentinels of the Forest (2014 to present)

Brazil nut trees and collective forest are common property in usufruct under authority of INCRA settlements created with low presence of INCRA, minimal presence of SEMA-MT or IBAMA; good relationships with local government

Short term support from the French Office Nationale de Forêts (ONF) for local conservation projects at the ONF Fazenda São Nicolão, located north of the settlement along the Juruena river:

Unauthorized land tenure with informal boundaries between users, enforced by local fiat; Individually owned cattle demarcated by branding 
SES second tier variables

(Ostrom, 2007; 2009)

GS5 Operational rules

GS7 Constitutional rules

GS8 Monitoring and sanctioning processes

PAJUR

800 Brazil nut trees are geo-referenced; Prices for Brazil nut products secured through contracts; Risk distributed across value chain; Tax relief on cooperatives reported production

1 association representing common interests within the settlement

Collective Environmental License tied to the collective LR, which provides environmental legality to the entire settlement, regardless of the land tenure status of individual beneficiaries outside of the reserve or their participation in Brazil nut processing

State agencies provide some limited support in monitoring of reserve; Certification of non-timber forest products based on Brazil Nuts harvested on the collective LR, based on sustainable management certification criteria; Outside of the collective reserve, 170 of $250(68 \%)$ of demarcated lots have INCRA recognized beneficiaries (as of 2012)
Black market land sales and land accumulation; Volatile prices; Producer risk; Taxable invoices for cattle sales difficult to obtain

6 associations representing fragmented interests within the settlement

From the administrative standpoint of a settlement-wide environmental registry (CAR), 150-200 families within the collective reserve may be 'invisible', as these users are not tied to demarcated lots; CAR rules are not matched with the existing resource system based on the historical occupation of the collective reserve

A settlement wide CAR will likely be unable to attribute deforestation to particular users inside the illegally occupied collective LR areas; No legal government mechanism exists to expel unauthorized users from collective reserve; No products involving the collective reserve are certified; Outside of the collective reserve, 461 of 524 (88\%) demarcated lots have INCRA recognized beneficiaries

Users $(U)$

U1 Number of users

U3 History of use

U5 Leadership/ entrepreneurship

U6 Norms/Social capital

U7 Mental models
Roughly 70 families participate in Brazil nut cooperatives

Settlers arrived in $\sim 1999 / 2000$, after lots and collective reserve demarcated by INCRA

PPG-7, GEF projects link settlement with development of cooperative enterprise based on extractivism and added-value processing

Social recognition and legitimacy of reserve, linked to state policies; Norms function independent of municipal politics and alliances (municipal authorities in cahoots with gold miners in 2004-5); Boundaries of the forest reserve are known; Settlers have informal system for monitoring the LR

Recognition of the collective LR as a viable commonly-managed asset $\sim 200$ families occupying collective forest reserve, each occupying 20 hectares mostly in pasture

Settlers arrive in 1997/8 before INCRA demarcated lots and collective LR areas in 2003

Initial efforts to create a cooperative disintegrated and led to more informal association for Brazil nut harvesting on properties external to the settlement

Social norm is the occupation of the collective reserve through productive use to secure tenure, which is linked to municipal politics; No social recognition or legitimacy of collective reserve

No appreciation of the collective LR areas as a commons 


\begin{tabular}{|c|c|c|}
\hline $\begin{array}{l}\text { SES second tier variables } \\
\text { (Ostrom, 2007; 2009) }\end{array}$ & PAVAM & PAJUR \\
\hline \multicolumn{3}{|l|}{ Interactions (I) } \\
\hline I5 Investment activities & $\begin{array}{l}\text { US } \$ 300,000 \text { supplied by international and } \\
\text { state agencies (GEF/UNDP, SEMA, } \\
\text { INCRA) for Brazil nut processing } \\
\text { infrastructure, and additional CONAB } \\
\text { working capital finance }(\$ 580,000)\end{array}$ & $\begin{array}{l}\text { Local municipal government provides } \\
\text { resources for road maintenance, including } \\
\text { unpaved roads within collective LR }\end{array}$ \\
\hline I8 Networking & $\begin{array}{l}\text { Settler association and cooperatives are } \\
\text { linked with Mato Grosso state and Federal } \\
\text { agencies via pilot projects }\end{array}$ & $\begin{array}{l}\text { Networking with municipal governments } \\
\text { for road maintenance and in obtaining } \\
\text { taxable sales invoices for cattle and other } \\
\text { product sales (even though land tenure is } \\
\text { unrecognized) }\end{array}$ \\
\hline I9 Monitoring activities & $\begin{array}{l}\text { Collective LR monitored against invasion } \\
\text { through community-based arrangements }\end{array}$ & $\mathrm{n} / \mathrm{a}$ \\
\hline \multicolumn{3}{|l|}{ Outcomes $(\mathrm{O})$} \\
\hline $\begin{array}{l}\text { O1 Social performance } \\
\text { measures }\end{array}$ & $\begin{array}{l}\text { Sustainable commons; Social and material } \\
\text { infrastructure favoring sustained, long } \\
\text { term economic returns; System functions } \\
\text { regardless of land tenure on individual lots } \\
\text { outside of the collective reserve }\end{array}$ & $\begin{array}{l}\text { Social concentration on economic returns } \\
\text { to minimal investment; Unsustainable, } \\
\text { lack of property rights encourages ongoing } \\
\text { 'frontier' dynamic; Private land } \\
\text { accumulation and increasing socio- } \\
\text { economic inequality are occurring, } \\
\text { regardless of the informal character of } \\
\text { land rights }\end{array}$ \\
\hline $\begin{array}{l}\text { O2 Ecological performance } \\
\text { measures }\end{array}$ & $\begin{array}{l}\text { Deforestation rates reduced to a minimum } \\
\text { by } 2010 ; 57 \% \text { forest cover retained for the } \\
\text { settlement as a whole (as of 2012) }\end{array}$ & $\begin{array}{l}\text { Significant uptick in deforestation rate } \\
\text { from } 2 \% \text { to } 5 \% \text { in } 2012 ; 37 \% \text { forest cover } \\
\text { retained for the settlement as a whole (as } \\
\text { of 2012) }\end{array}$ \\
\hline
\end{tabular}

